\title{
Recombinant Human CD4 Immunoglobulin
}

National Cancer Institute

\section{Source}

National Cancer Institute. Recombinant Human CD4 Immunoglobulin. NCI Thesaurus. Code C51979.

An immunoconjug ate of recombinant CD4 antigen (rCD4) covalently linked to an immunog lobulin G heavy chain with activity against human immunodeficiency virus (HIV). Recombinant CD4 antigen competitively binds to the envelope glycoprotein gp120 of HIV, prevents the attachment of gp120 to CD4 on T lymphocytes, and acts as an HIV fusion inhibitor; the immunog lobulin G portion extends the length of time that rCD4 stays in the body. 